\title{
PENERAPAN VALUE ENGINEERING (VE) PADA PEMBANGUNAN GEDUNG KAMPUS II UNIVERSITAS MUHAMMADIYAH PALANGKARAYA
}

\author{
${ }^{1)}$ Hendra Cahyadi \\ ${ }^{2)}$ Rida Respati \\ ${ }^{3)}$ Galibur Rahman \\ ${ }^{1)}$ Tekni Sipil Universitas Islam Kalimantan Muhammad Arsyad Al Banjari \\ E-mail : irarizqonroyan@gmail.com \\ ${ }^{2)}$ Teknik Sipil Universitas Muhammadiyah Palangkaraya \\ E-mail : ridares@gmail.com \\ ${ }^{3)}$ Teknik Sipil Universitas Muhammadiyah Palangkaraya \\ E-mail : galibursipilump@gmail.com
}

\begin{abstract}
ABSTRAK
Menganalisa kembali sebuah perencanaan pembangunan gedung menjadi salah satu pilihan untuk menghemat biaya, namun masih sesuai ketentuan dan standar yang berlaku. Banyak alternatif yang digunakan untuk menghemat biaya-biaya dengan mengurangi atau menghilangkan biaya yang tidak diperlukan. Salah satu alternatif yang dapat digunakan adalah value engineering (rekayasa nilai). Value Engineering (VE) dapat didefinisikan sebagai sebuah teknik dalam manajemen pendekatan yang sistematis untuk mencari keseimbangan fungsi terbaik antara biaya, kendala kinerja sebuah proyek serta mengurangi atau menghilangkan biaya yang tidak penting.
\end{abstract}

Pada penelitian ini analisa VE dilakukan berdasarkan item yang dianalisis menggunakan distribusi Paretto, kemudian selanjutnya dilakukan analisa dengan beberapa tahap/ fase yaitu tahap informasi, tahap kreatif, tahap analisa dan tahap rekomendasi. Untuk Rancangan Anggaran Biaya dikelompokan lebih ringkas menjadi beberapa kelompok selanjutnya dilakukan distribus Paretto sehingga diperoleh item yang akan dilakukan Value Engineering yaitu Pekerjaan Struktur, Pekerjaan Dinding, Lantai dan Plafond serta Pekerjaan Saluran dan Ruas Jalan.

Rancangan usulan yang diterapkan pada studi ini adalah penggantian item pondasi Konstruksi Sarang Laba-Laba menjadi Bored Pile ditambah dengan pekerjaan yang menyertainya sehingga diperoleh selisih biaya untuk pekerjaan struktur sebesar Rp. 435.419.421. Rancangan usulan pekerjaan dinding hanya mengganti partisi dinding dari Gypsum board $5 \mathrm{~mm}$ (kayu kelas II) menjadi Triplek $6 \mathrm{~mm}$ sehingga diperoleh selisih biaya sebesar Rp. 17.034.473. Rancangan pada pekerjaan ruas jalan hanya me-review untuk pemanacangan galam per- $\mathrm{m}^{2}$ dengan selisih biaya 
Rp. 1.050.000.000. Berdasarkan perhitungankeseluruhan total biaya hasil yang diperoleh pada studi penerapan valueengineering ini relatif kecil yaitu hanya berkisar 7,4\% dari total kesuluruhanbiaya.

Kata kunci: rancangan anggaran biaya, rekayasa nilai, gedung

\begin{abstract}
Re-analyzinga building development plan to be anoption to save costs, but still in accordance with applicable terms and standards. Many alternatives are used to save costs by reducing or eliminating unnecessary costs. One of the alternatives that can be used is value engineering (VE). Value Engineering (VE) can be defined as atechnique in the management of a systematic approach to finding the best balance of functions between cost, performance constraints of a project and reducing or eliminating unnecessary costs.

In this research VE analysis is done based on the items analyzed using Paretto distribution, then next done by analysis with some phase/phase that is stage information, creative phase, analysis phase and recommendation phase. For the Budget Plan, it will bedivided into several groups, then distributed by Paretto so that the items will be done Value Engineering is Structural Work, Wall Work, Floor and Ceilingas wellas Channel and Road Works.
\end{abstract}

The proposed draft applied in this study is there placement of the foundation of the Sarang Laba-Laba Construction to Bored Pile plus the accompanying work so that the cost difference for the structural work is Rp. 435,419,421. The proposed wall work only replaces the wall partition of Gypsumboard $5 \mathrm{~mm}$ (class II wood) into Triplek $6 \mathrm{~mm}$ so that the cost difference of Rp.17.034.473. The design on the road works is only reviewed for perforation of the 2 nd marine with a cost difference of Rp.1.050.000.000. Based on th ecalculation entire of the cost of the results obtained in the study of the application of value engineering is relatively small that is only about $7.4 \%$ entire of cost.

Keywords: budget draft, value engineering and building

\title{
PENDAHULUAN
}

Rencana Anggaran Biaya (RAB) pada sebuah pembangunan gedung dihitung setelah perhitungan konstruksi bangunan selesai. Hal tersebut terkait dengan desain dan bahan dalam perencanaan pembangunan gedung tersebut. Beberapa elemen bangunan gedung ada yang memiliki biaya besar pada beberapa segmen pengerjaannya. Biaya yang bernilai besar tersebut memilliki pengaruh pada biaya proyek secara keseluruhan. Biaya pada beberapa segmen tersebut dipengaruhi oleh berbagai aspek, diantaranya dilihat dari segi pemilihan bahan, cara pengerjaan, waktu pelaksanaan, 
jumlah tenaga kerja dan lain-lain. Namun elemen pembangunan gedung tersebut dapat dioptimalkan dengan pengefisienan kembali.

Menganalisa kembali sebuah perencanaan pembangunan gedung menjadi salah satu pilihan untuk menghemat biaya, namun masih sesuai dengan ketentuan dan standar yang berlaku. Banyak alternatif yang digunakan untuk menghemat biaya-biaya dengan mengurangi atau menghilangkan biaya yang tidak diperlukan. Salah satu alternatif yang dapat digunakan adalah value engineering (rekayasa nilai).

Value Engineering (rekayasa nilai) dapat didefinisikan sebagai sebuah teknik dalam manajemen pendekatan yang sistematis untuk mencari keseimbangan fungsi terbaik antara biaya, kendala kinerja sebuah proyek serta mengurangi atau menghilangkan biaya yang tidak penting. Hal tersebut muncul karena sering kali ditemukan biaya yang tidak diperlukan terjadi dalam suatu proyek.

Berdasarkanuraiantersebut,maka perludilakukan penerapan value engineering yang diharapkan mampu menjadi alternatif pengganti item pekerjaan lama sebagai rekomendasi dari pihak terkait, yang mampu memberikan cost saving/penghematan biaya. Pada penelitian ini mengambil studi kasus pada pembangunan gedung kampus II Universitas Muhammadiyah Palangkaraya.

\section{METODE PENELITIAN}

\section{Tempat Penelitian}

Data yang digunakan untuk penelitian ini diperoleh dari sumber data dan survei di proyek pembangunan gedung Kampus II Universitas Muhammadiyah Palangkaraya yang terletak di Jalan Anggrek Mahir Mahar Palangka Raya.

\section{Teknik Pengumpulan Data}

Beberapa data yang dikumpulkan untuk penelitian ini terdiri dari dua kategori :

1. Data Primer merupakan data yang didapat melalui pengamatan langsung di lapangan. Data ini diperoleh melalui wawancara dengan responden (suplier) berupa data harga material.

2. Data Sekunder adalah data yang diperoleh dengan mengutip data yang sudah ada melalui narasumber di proyek. Data tersebut berupa gambar kerja, Rencana Anggaran Biaya dan Rencana Kerja serta syarat-syaratnya.

\section{Analisa Data}

Pada penerapan Value Engineering untuk proyek ini digunakan tahapan analisa yang terdiri dari tahap informasi, tahap analisa fungsional, tahap kreatif, tahap evaluasi, tahap pengembangan, tahap penulisan, tahap presentasi. Penjelasan sebagai berikut:

1. Tahap Informasi, tahap ini bertujuan untuk mendapatkan permasalahan yang jelas atas proyek yang akan dilakukanValueEngineering dan untuk mengetahui bagianbagian mana dari proyek yang strategis untuk dikaji. Prinsip tahap informasi 
adalah identifikasi biaya tinggi dan identifikasi biaya yang tidak diperlukan. Dalam identifikasi biaya tinggi pertamakali dilakukan pembuatan cost model. Menurut Dell'Isola, A (1975) menjelaskan bahwa cost model adalah model yang digunakan untuk menggambarkan distribusi biaya total proyek. Kemudian membuat Break down analysis dengan mengurutkan biaya pekerjaan paling tinggi sampai ke paling rendah. Selanjutnya menarik batas dalam Breakdown Analysis dengan bantuan grafik Hukum distribusi Pareto. Kemudian untuk mengidentifikasi biaya yang tidak diperlukan adalah dengan mengidentifikasi item pekerjaan melalui analisa fungsi berdasarkan fungsinya dalam perbandingan biaya dengan manfaat (cost/worth)

2. Tahap Kreatif, tahap ini bertujuan untuk mendapatkan dan mengembangkan alternatif sebanyak-banyaknya dan sebaik-baiknya untukmemenuhifungsiutama dari halyang dikaji. Kegiatanyangdilakukan adalah melakukan divergensi dengan brainstorming dan melakukan pencatatan untuk evaluasi

3. Tahap Analisa, Tahap ini dilakukan analisa keuntungan dan kerugian pada alternatif yang dihasilkan pada tahap kreatif. Tiap alternatif dicatat keuntungan dan kerugiannya, kemudian diberi bobot nilai sesuai kriteria dan disusun peringkatnya. Ada beberapa kriteria yang digunakan yaitu keawetan, biaya, kekuatan, estetika, pelaksanaan, perawatan dan waktu pelaksanaan. Alternatif yang memiliki skor tertinggi akan dianalisis pada tahap selanjutnya yaitu Life Cycle Cost (LCC) dan selanjutnya yaitu mendapatkan alternatif pilihan dengan metode Analytical Hierarchy Process (AHP). Menurut L.Saaty (1994) metode ini dipilih karena dalam membuat perbandingan, dibutuhkan skala nilai yang mengindikasikan seberapa pentingnya satu elemen dengan yang lainnya sehubungan dengan kriteria yang dibandingkan. Dalam metode ini diberikan skala tingkat kepentingan1-9 antar elemen. Setelah melakukan pembobotan kriteria, maka dipilih satu alternatif terbaik dari tiap item pekerjaan yang mempunyai nilai terbesar dari perkalian antara bobot dengan nilai.

4. Tahap Rekomendasi, Pada tahap ini dilakukan perekomendasian dari alternatif yang terpilih. Pada penelitian ini hanya merekomendasi dalam bentuk tabel dan mencantumkan perbandingan antara desain lama dengan desain usulan dan besarnya penghematan. Secara umum pelaksanaan penelitian dapat dilihat pada Gambar 1 berikut ini. 
JURNAL KACAPURI

JURNAL KEILMUAN TEKNIK SIPIL

Volume 1 Nomor 2 Edisi Desember 2018

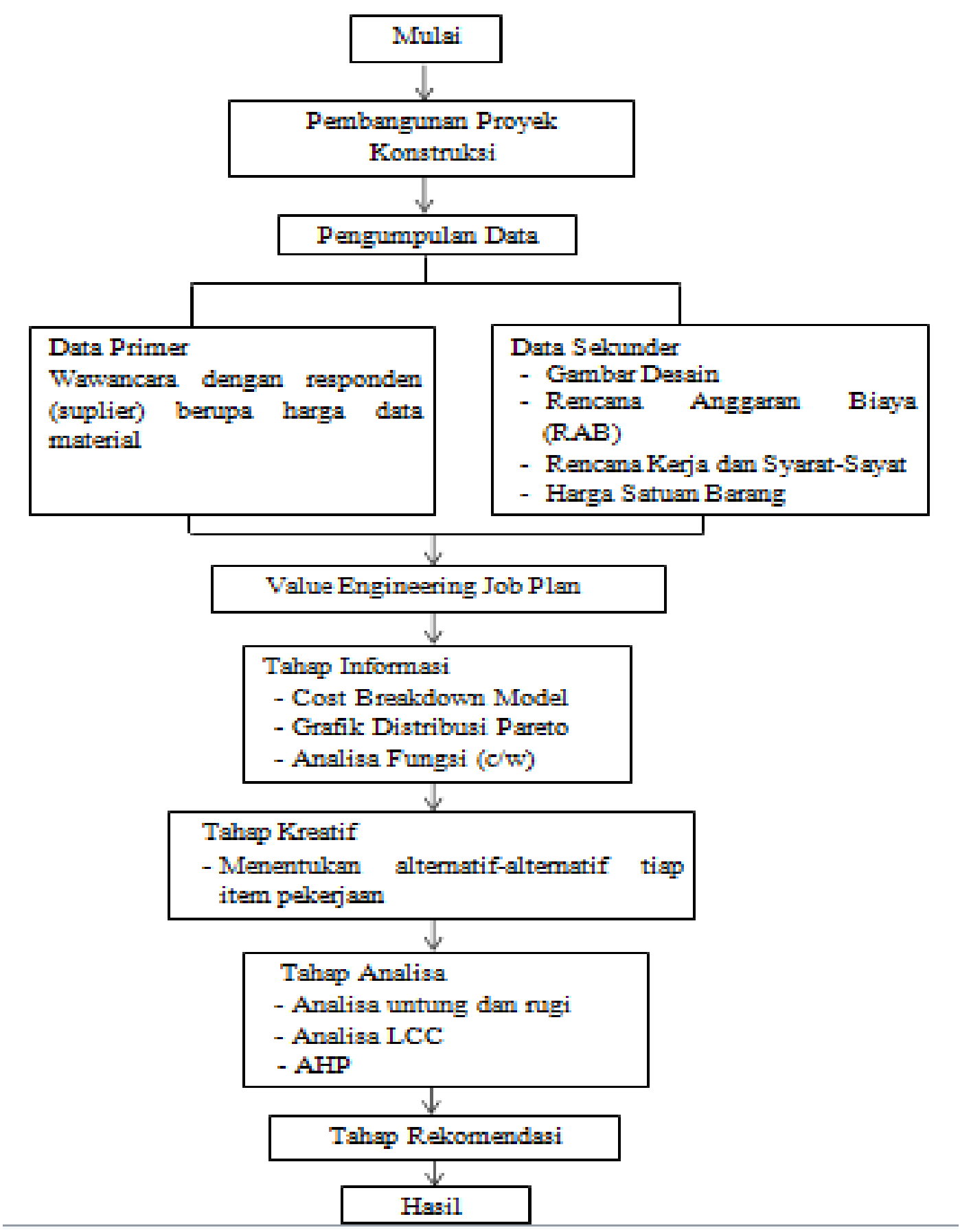

Gambar 1. Bagan Alir Penelitian 


\section{HASIL \&PEMBAHASAN}

\section{Gambaran Umum}

Dewasa ini, seiring dengan berkembangnya ilmu pengetahuan dan teknologi, maka Provinsi Kalimantan Tengah saat ini sedang giat-giatnyamelaksanakan program peningkatan pendidikan di segala bidang agar dapat segera mensejajarkan diri dengan provinsi lainnya. Universitas Muhammadiyah Palangkaraya merupakan Universitas swasta yang ada di Kalimantan Tengah. Seiring dengan meningkatnya kebutuhan akan ilmu pengetahuan ke jenjang yang lebih tinggi, maka kebutuhan akan sarana dan prasana pendidikan meingkat. Seiring dengan itu diperlukan sarana dan prasarana pendukung, salah satunya adalah proyek pembangunan gedung kampus Universitas Muhammadiyah Palangkaraya yang merupakan pembangunan gedung baru pada Universitas Muhammadiyah Palangkaraya. Gedung tersebut berada di Jalan Anggrek Mahir Mahar Palangka Raya. Digunakan sebagai gedung perkantoran dan rektorat mengingat lahankampus utama yang lama sudah tidak cukup memenuhi kebutuhan kegiatan akademika. Sehingga dengan dibangunnya gedung kampus II Universitas Muhammadiyah Palangkaraya ini akan menambah predikat baik padasarana dan prasarana kampus dengan luas lahan yang memadai untuk dibangun sebuah kampus dengan desain yang luas. Dengan adanya pembangunan gedung kampus II tersebut maka diharapkan kualitas pendidikan pada Universitas Muhammadiyah Palangkaraya semakin meningkat.

Tabel 1. Data Proyek

\begin{tabular}{|l|l|l|}
\hline Program & $:$ & Peningkatan Sarana dan Prasarana Apartur \\
\hline Kegiatan & $:$ & Pembangunan Gedung Kantor \\
\hline Pekerjaan & $:$ & $\begin{array}{l}\text { Pembangunan Gedung BAU, BAAK dan LP3MPT } \\
\text { Universitas Muhammadiyah Palangkaraya }\end{array}$ \\
\hline Pemberi Tugas & $:$ & Universitas Muhammadiyah Palangkaraya \\
\hline Lokasi & $:$ & Jalan Anggrek (Lingkar Luar) km. 1,5 Palangka Raya \\
\hline Bentuk Bangunan & $:$ Bangunan Gedung Bertingkat \\
\hline Biaya Fisik & $:$ & Rp. 20.262.300.000 \\
\hline Pondasi & $:$ & $\begin{array}{l}\text { Footplate dengan konstruksi sarang laba-laba. } \\
\text { Menggunakan cor beton dengan mutu K-225 }\end{array}$ \\
\hline Struktur & $: \begin{array}{l}\text { Pekerjaan struktur (Kolom, Balok, Plat Lantai, Dak } \\
\text { Atap) menggunakan mutu beton K-225. }\end{array}$ \\
\hline $\begin{array}{l}\text { Dinding Lantai dan } \\
\text { Plafond }\end{array}: \begin{array}{l}\text { Dinding menggunakan 1/2 bata camp. 1:4. Partisi } \\
\text { dinding menggunakan gypsumboard kayu kelas II. Lantai } \\
\text { menggunakan keramik. Pekerjaan plafond menggunakan } \\
\text { rangka plafond besi hollow, penutup plafond PVC dan } \\
\text { list plafond gypsum }\end{array}$ \\
\hline $\begin{array}{l}\text { Drainase dan ruas } \\
\text { jalan }\end{array}$ & $\begin{array}{l}\text { Pekerjaan ruas jalan beton bertulang menggunakan beton } \\
\text { mutu K- 250. }\end{array}$ \\
\hline
\end{tabular}

\section{Bagian Konstruksi yang Akan Dilakukan Value Engineering}


Untuk menentukan item-item yang akan dilakukan Value Engineering digunakan metode "Breakdown Analysys" sehingga dapat dilihat urutan pekerjaan yang memerlukan biaya paling besar sampai keurutan biaya yang paling kecil. Tabel 2 berikut merupakan urutan pekerjaan dari biaya terbesar sampai terkecil

Tabel 2. Urutan Pekerjaan Biaya Terbesar ke Terkecil

\begin{tabular}{|l|l|r|}
\hline No & \multicolumn{1}{|c|}{ Pekerjaan } & \multicolumn{1}{c|}{ Biaya (Rp) } \\
\hline 1 & PEKERJAAN STRUKTUR & 10.430 .023 .019 \\
\hline 2 & PEKERJAAN DINDING, LANTAI DAN PLAFOND & 3.887 .229 .491 \\
\hline 3 & PEKERJAAN SALURAN DAN JALAN & 2.591 .679 .372 \\
\hline 4 & PEKERJAAN LAIN-LAIN & 1.218 .810 .000 \\
\hline 5 & PEKERJAAN PINTU, JENDELA DAN AKSESORIS & 851.542 .681 \\
\hline 6 & PEKERJAAN PENGECATAN & 645.132 .811 \\
\hline 7 & EKERJAAN ELECTRIKAL DAN SANITASI AIR & 487.980 .000 \\
\hline 8 & PEKERJAAN PERSIAPAN & 150.000 .000 \\
\hline & BIAYA FISIK KONSTRUKSI BANGUNAN & $\mathbf{2 0 . 2 6 2 . 3 9 7 . 3 7 4}$ \\
\hline & DIBULATKAN & $\mathbf{2 0 . 2 6 2 . 3 0 0 . 0 0 0}$ \\
\hline
\end{tabular}

Menurut hukum Paretto $20 \%$ item yang terpilih harus mempunyai total cost $80 \%$ dari total biaya maka :

Distribusi Paretto= Jumlah item $\times 20 \%$

$$
\begin{aligned}
& =9 \times 20 \% \\
& =1,8 \text { item } \sim 2 \text { item }
\end{aligned}
$$

Dari perhitungan distribusi tersebut dapat diambil 2 item pekerjaan dengan biaya paling besar, kemudian dilakukan perhitungan untuk mengetahui 2 item tersebut sudah memenuhi $80 \%$ dari total biaya atau masih belum memenuhi. Berikut perhitungan untuk mengetahui prosentase biaya dari item terpilih:

Pekerjaan Struktur

Pekerjaan Dinding, Lantai Dan Plafond

Total
10.430 .023 .019

3.887.229.491

14.317.252.510

$\%$ biaya terpilih terhadap biaya total $=(14.317 .252 .510 / 20.262 .300 .000) \times 100$

$$
=70,66 \%
$$

Hasil tersebut menunjukan bahwa 2 item tersebut belummemenuhi $80 \%$ biaya dari biaya total. Untuk memenuhi prosentase tersebut, maka dapat diambil item tambahan yang memiliki biaya besar atau item yang berkaitan atau berpengaruh pada 2 item tersebut.

Pekerjaan Struktur

Pekerjaan Dinding, Lantai Dan Plafond

Pekerjaan Saluran dan Jalan

Total

$\%$ biaya terpilih terhadap biaya total $=(16.908 .931 .882 / 20.262 .300 .000) \times 100$

$$
=83,45 \%
$$

10.430.023.019

3.887.229.491

2.591.679.372

16.908 .931 .882

$62.300 .000) \times 100$

64 
Maka 2 item terpilih berserta item tambahannya diamemenuhi syarat untuk dilakukan Value Engineering. Hasil analisis Paretto dapat dilihat pada Gambar 2 berikut

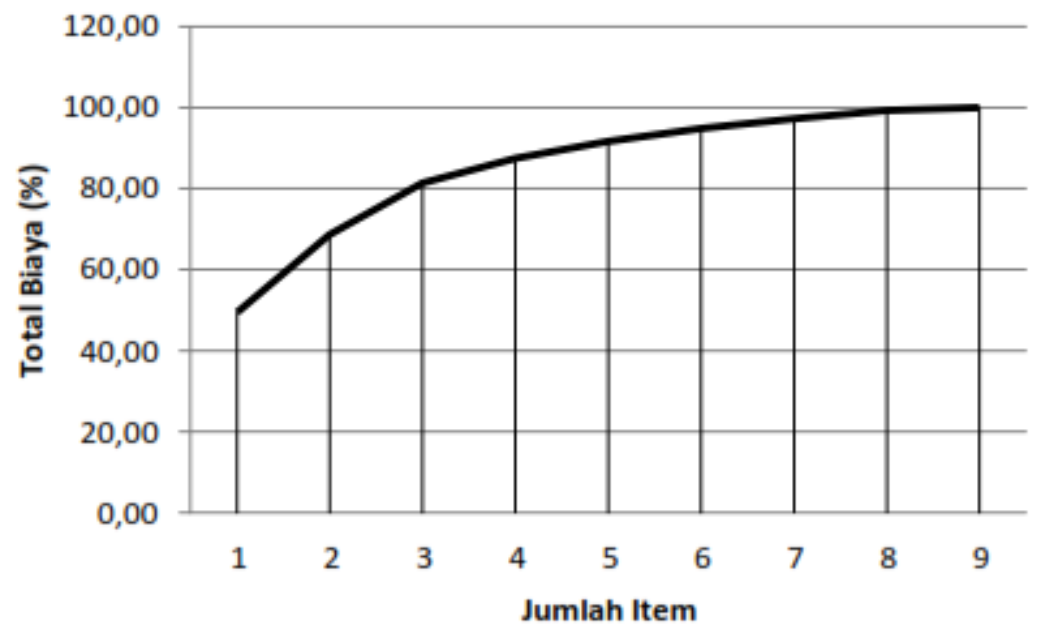

Gambar 2. Grafik Distribusi Paretto Item Terpilih

\section{Rekomendasi Hasil Rekayasa Nilai}

Setelah dilakukan analisa dari tahap-tahap kreatif yang dipilih, maka dibuat rekomendasi hasil studi dari value engineering. Berikut disajikan rekomendasi dalam bentuk tabel berikut ini:

Tabel 3. Rekomendasi Hasil Value Engineering

\begin{tabular}{|l|c|l|}
\hline \multicolumn{3}{|c|}{ TAHAP REKOMENDASI } \\
\hline Proyek/Program & $:$ & $\begin{array}{l}\text { Pembangunan Gedung Kantor/Peningkatan } \\
\text { Sarana dan Prasarana Apartur }\end{array}$ \\
\hline Lokasi & $:$ & Jalan Anggrek (Lingkar Luar) km.1,5 Palangka Raya \\
\hline Pekerjaan & $:$ & $\begin{array}{l}\text { Pembangunan Gedung BAU, BAAK dan LP3MPT } \\
\text { Universitas Muhammadiyah Palangkaraya }\end{array}$ \\
\hline RencanaAwal & $:$ & $\begin{array}{l}\text { 1. Struktur Pondasi dengan Konstruksi Sarang Laba- } \\
\text { Laba } \\
\text { Pekerjaan Dinding Partisi dengan Gypsum } \\
\text { board 5 mm (Kayu KelasII) }\end{array}$ \\
\hline Usulan & $:$ & $\begin{array}{l}\text { 1. Struktur Pondasi dengan Pondasi Bored } \\
\text { Pile beserta pekerjaan Foot Plate dan Sloof } \\
\text { ukuran }\end{array}$ \\
2. Pekerjaan dinding partisi dengan Triplek \\
6 mm120 x 240
\end{tabular}




\begin{tabular}{|l|l|l|}
\hline & $\begin{array}{l}\text { kuisioner untuk mengetahui pengisian setiap item } \\
\text { pekerjaan. }\end{array}$ \\
\hline
\end{tabular}

Untuk lebih jelasnya, berikut ini ditampilkan gambar-gambar tahap rekomendasi yang diusulkan

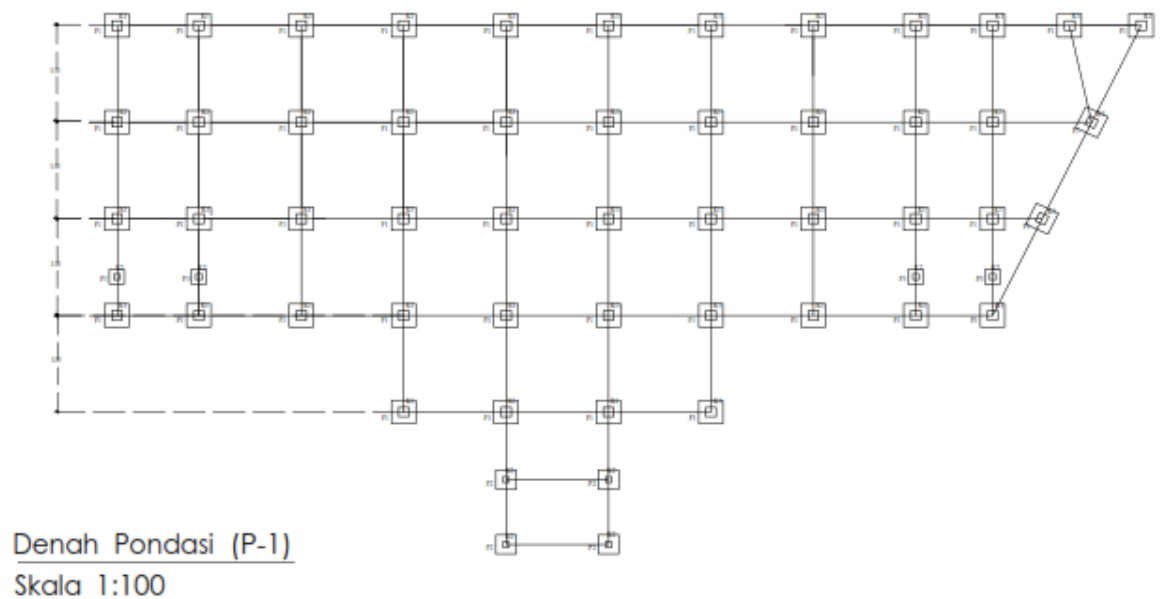

Gambar 3. Denah Pondasi Foot Plate untuk Bore Pile

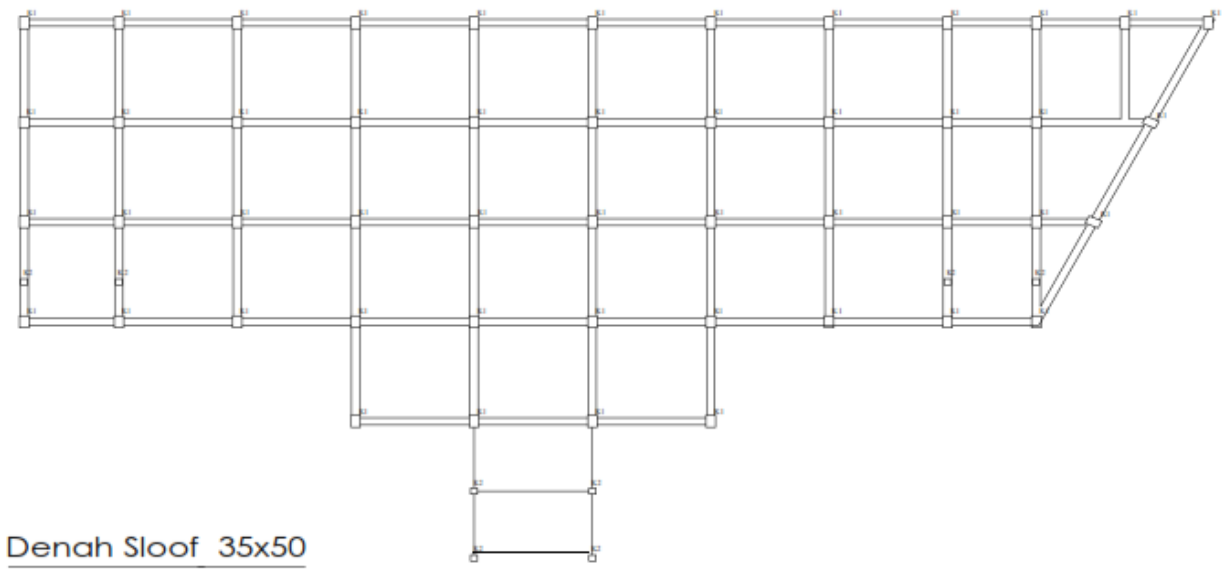

Skala 1:100

Gambar 4. Denah Sloof ukuran 35x50 


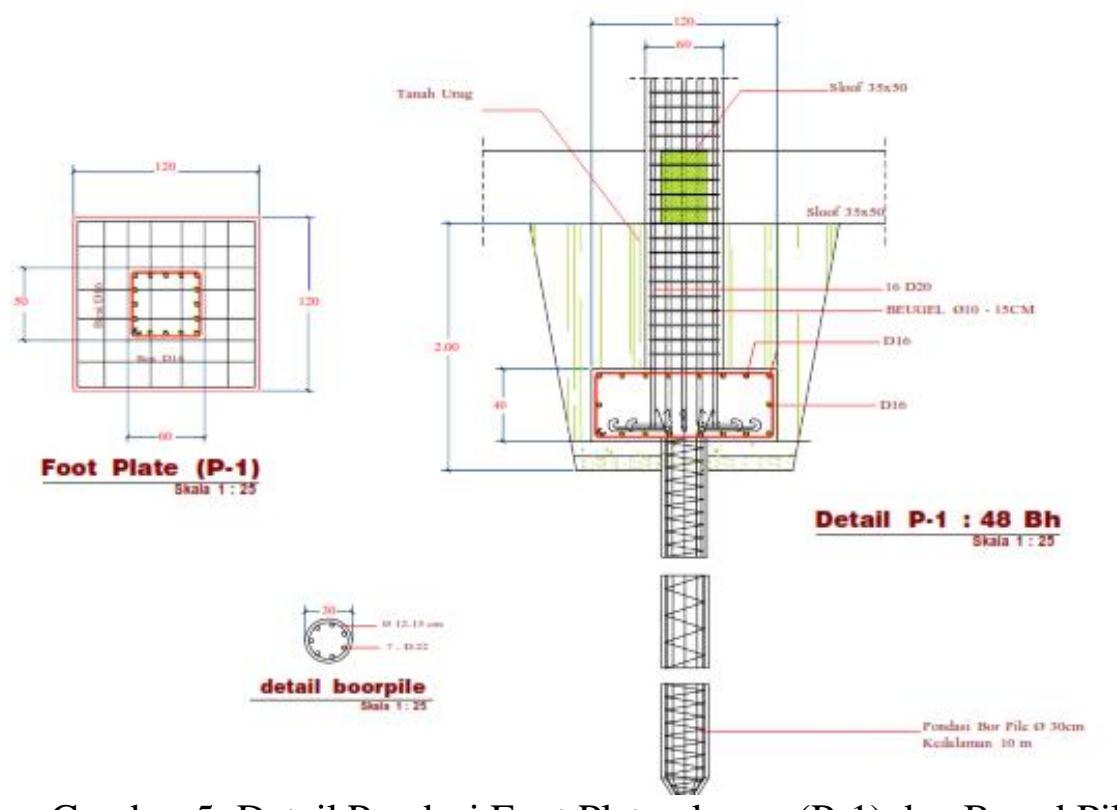

Gambar 5. Detail Pondasi Foot Plate ukuran (P-1) dan Bored Pile

\section{PENUTUP}

Berdasarkan hasil studi value engineering (VE) pada pembangunan Gedung Kantor Kampus II Universitas Muhammadiyah Palangkaraya dapat disimpulkan sebagai berikut:

1. Value Engineering adalah suatu metode evaluasi yang menganalisa teknik dan nilai dari suatu proyek atau produk yang melibatkan: pemilik, perencana dan para ahli yang berpengalaman dibidangnya masing-masing dengan pendekatan sistematis dan kreatif yang bertujuan untuk menghasilkan mutu dan biaya serendah-rendahnya yaitu dengan batasan fungsional dan tahapan rencana tugas yang dapat mengidentifikasi biaya-biaya dan usaha yang tidak diperlukan atau kurang mendukung.

2. Proses value engineering pada studi ini menerapkan beberapa tahap/fase seperti tahap informasi, tahap kreatif, tahap analisa/pengembangan serta tahap rekomendasi.

3. Prinsip-prinsip value engineering dapat diterapkan pada pembangunan Gedung Kantor Kampus II Universitas Muhammadiyah Palangkaraya.

4. Pekerjaan yang dipilih untuk diterapkan value engineering adalah item yang dianalisis berdasar distribusi pareto yaitu $20 \%$ pekerjaan yang menghabiskan $80 \%$ dari biaya total atau dapat disertai item tambahannya.

5. Rancangan usulan yang diterapkan pada studi ini adalah penggantian item pondasi Konstruksi Sarang Laba-Laba menjadi Bored Pile ditambah dengan pekerjaan yang menyertainya sehingga diperoleh selisih biaya untuk pekerjaan struktur sebesar Rp. 435.419.421.

6. Rancangan usulan pekerjaan dinding hanya mengganti partisi dinding dari 
Gypsumboard 5 mm (kayu kelas II) menjadi Triplek $6 \mathrm{~mm}$ sehingga diperoleh selisih biaya sebesarRp. 17.034.473.

7. Rancangan pada pekerjaan ruas jalan hanya me-review untuk pemanacangan galam per- $\mathrm{m}^{2}$ dengan selisih biaya Rp. 1.050.000.000.

8. Berdasarkan perhitungan keseluruhan total biaya hasil yang diperoleh pada studi penerapan value engineeringi ni relatif kecil yaitu hanya berkisar 7,4\% dari total kesuluruhan biaya.

\section{DAFTAR PUSTAKA}

Alabd, A.A.K. Pandey, R.K. 2016. Concept of Value Engineering in Construction Industry. International Journal ofScienceand Research (IJSR). Volume 5 Issue 4, April 2016

Asty, P.N.2014. Analisa Value Engineering pada Proyek Gedung Riset dan Museum Energi dan Mineral Institut Teknologi Bandung. Jurnal Teknik Sipil dan Lingkungan, Vol.2,No.1, Maret 2014

Giatman, M. 2011. Ekonomi Teknik. Raja Grafindo Persada. Jakarta

Ibrahim,B.2012. Rencana dan EstimateReal of Cost. BumiAksara. Jakarta

Priyo,M.Dwi,H.T. 2010. Aplikasi Value Engineering pada Proyek Konstruksi (Studi Kasus :Proyek Pembangunan Gedung BPKP Yogyakarta). Jurnal Ilmiah Semesta Teknika. Vol. 13, No.2, Hal.115-129, November 2010

Puji, L.S. 2011. Penerapan Value Engineering Untuk Efisiensi Biaya Pada Proyek Bangunan Gedung Berkonsep Green Building (Studi Kasus : Proyek Pembangunan Gedung Menteri). Skripsi Program Sarjana Teknik Sipil Universitas Indonesia Depok

Santoso,H. 2012. Aplikasi Value Engineering Terhadap Struktur Blok dan Pondasi Untuk Proyek Pembangunan IGD RSUD Buntok Barito Selatan. Skripsi Program Studi Teknik Sipil Universitas Muhammadiyah Palangkaraya

Shanty, K.A. D.R.O. Walangitan, J.T. (2016). Penerapan Value Engineering pada Proyek Pembangunan Gereja GMIM Syaloom Karombasan. Jurnal Sipil Statik. Vol. 4, No.2, Februari 2016 (95-103) ISSN: 2337-6732

Yogi, W.A. Utomo, C. (2012). Penerapan Value Engineering pada Pembangunan Proyek Universitas Katolik Widya Mandala Pakuwon City - Surabaya. Jurnal Teknik ITS Vol.1, No. 1, (September) 2012 ISSN : 2301-9271

Zetha, R.H. Sesmiwati. (2014). Analisa Penerapan Value Engineering pada Industri Konstruksi di Indonesia. Jurnal Teknik FTUP.Vol27, No.2, Juni2014, Hal. 119-126 